\title{
UNA METÁFORA CERVANTINA: EL NORTE DE LA CABALLERÍA ANDANTE
}

1. El punto de partida es la concepción tradicional de la metáfora, magistralmente presentada en las obras de Stephen Ullmann; aceptamos también su clasificación en metáforas antropomórficas, animales y sinestésicas, a las que el lingüista húngaro añade una cuarta metáfora donde las experiencias abstractas se expresan por medio de términos concretos.

Querríamos tomar en consideración unas metáforas en $E l$ Quijote donde un término concreto sustituye a otro: tertium comparationis es una cualidad del mundo material, luminosidad, y el término sustitutivo, metafórico, que contiene el sema /luminosidad/, sustituye al nombre de persona que es muy a menudo - aunque no exclusivamente - el héroe de la novela.

2. Por cierto, en El Quijote para señalar el personaje hay metáforas donde se invocan otros trechos de carácter en común; los términos metafóricos no expresan luminosidad:

El espejo de la caballería (...) la flor y la nata de la gentileza (I/29)

¡Oh, flor de la andante caballería! (II/7)

Del gran Sancho Panza, flor y espejo de todos los insulanos gobernadores (II/52)

¡Dios te guíe, nata y flor de los andantes caballeros! (II/56)

Con todo, las metáforas con el sema /luminosidad/ son frecuentes y los términos metafóricos son varios: luz, lucero, lanterna, farol, sol, norte. Son fuertes y conocidas en todo tiempo. Para citar un poeta esloveno, Oton Župančič (1878-1949): svetel konj-zarje val "caballo fulgente - oleada de aurora". Tales metáforas sobresalen más porque la luminosidad de un cuerpo incluye la idea de atracción. No siempre el término metafórico sustituye el nombre del personaje: en Amadís fue el norte, el lucero, el sol de los valientes y enamorados caballeros (I/25), en Siendo él /Sancho/ su norte, su lanterna y su lucero tendrian buen fin sus negocios (II/53), el término metaforizado podría ser "guía", "ideal". Aun en estos casos la metáfora es pura, para recorrer a la terminología del Diccionario de términos filológicos de Lázaro Carreter ( $\mathrm{B}$ en lugar de $\mathrm{A}$ ); claro, el término metafórico no sustituye al nombre de persona. Hay otros pasos donde se verifica tal sustitución: Luz y espejo de la caballería manchega (I/9), ¡Oh, luz resplandeciente de las armas! (II/7), Don Quijote, de la Mancha esplendor, de España estrella (II/35), iLuz y farol, sendero, norte y guia de aquellos que (...) se acomodan a usar el ejercicio (...) de las armas! /palabras del disfrazado en el mago Merlín/ (ibid.), Bien sea venido a nuestra ciudad el espejo, el farol, la estrella y el norte de toda la caballería andante (II/61). 
3. Nos interesa en modo particular el uso del nombre de un astro luminoso, de estrella polar. Por el procedimiento metonímico - contigüidad de sentido - aparece bajo el nombre de uno de los cuatro puntos cardinales, el norte. Ahora bien, como se considera una metáfora más fuerte cuanto más distantes son los campos conceptuales (sustituir, por ejemplo, el nombre de una flor al de una otra seria metáfora apropiada, pero ineficaz), el doble procedimiento de sustitución, metonímico y metafórico, hace tal metáfora más fuerte aún.

En El Quijote, el término norte no está usado siempre metafóricamente; aparece en su sentido original, es decir, de punto cardinal, también en forma adjetiva: No soplaron sino vientos Nortes (II/4). Constatado ya por Julio Cejador y Frauca, La lengua de Cervantes (1905), norte aparece metonímicamente sustituyéndose a estrella polar:

¡Ay de aquel que navega, el cielo escuro.

Por mar no usado y peligrosa vía.

Adonde norte o puerto no se ofrece! (I/34)

Por ella dejé la casa de mi padre, y por ella me puse en este traje, para seguirla dondequiera que fuese, como la saeta al blanco, o como el marinero al norte. (I/44)

En los pasos citados norte se sustituye a estrella polar en el sentido de "punto de apoyo, de justa dirección". En tal sentido entendemos norte en las palabras de Isabel calderoniana (El alcalde de Zalamea, III): discurri, bajé, corrí, sin luz, sin norte, sin guía. El sentido es bastante concreto.

Lo es menos en los ejemplos que aduce el Diccionario de Autoridades (1732): "NORTE. Metaphoricamente vale guia, tomada la alusión de la estrella del Norte, por la qual se guian los navegantes, con la dirección de la agúja náutica." El Diccionario de la lengua española, vigésima edición, de la Real Academia Española (1984), s.v. norte, diccionario sin ejemplos par excellence, no hace sino repetir casi con las mismas palabras la definición del Diccionario de Autoridades: "Dirección, guía, con alusión a la Estrella polar que sirve de guía a los navegantes." Pero el Diccionario de Autoridades añade ejemplos literarios donde norte aparece usado metafóricamente y menos concreto: Para gloria de Dios y bien de su Santa Iglésia, que es el fin y norte à que él atienda con todos ellos. Un ejemplo análogo, moderno, lo ofrece el Diccionario de uso del español de María Moliner (1966): La prosperidad del pais debe ser nuestro norte.

El uso de norte como "ideal abstracto", "modelo de seguir" tiene que ser muy literario. Es apenas posible encontrarlo en la lengua de hoy; para la lengua hablada, espontánea, el uso es poco creíble. Bahner, El español coloquial, $2 .^{\mathrm{a}}$ ed. española (1968), no lo registra. Me anoté, todavía, pero no es lengua coloquial, aunque hablada, en el noticiario de Radio Exterior de España, Servicio mundial, 26-IX-91: El equipo español contra Islandia jugó sin algün norte.

4. No nos son de ayuda las demás lenguas románicas. Sí, en el francés moderno existe la frase perdre le nord; se encuentra, nos asegura Le Grand Robert, Dictionnaire historique de la langue française (1992), ya en 1572. Pero, sólo en esta estructura fraseológica. En italiano, nord no aparece ni en la Divina Comedia ni en el Decamerón. El UTET, el gran 
diccionario del italiano lieterario, cita, s.v. norte, un solo paso de Riccardo Bacchelli: $I l$ timor di Dio è il nord dell' anima, è se l'ago impazzisce, la rotta è persa.

5. Norte en el sentido de "estrella polar", como metonimia, y en el de "modelo" o incluso de "personaje de seguir", como metáfora, despierta un interés más: en la esfera cultural europea de los puntos cardinales el más importante es el oriente: nos orientamos, buscamos la orientación, concreta y figuradamente. En la jerga militar de algunas lenguas eslavas existe, y puede ser que provenga del alemán, orientir, "punto de servir de orientación". En las lenguas europeas el terrícola no recurre a los astros para orientarse: nos basta el Sol.

En la búsqueda del origen del empleo traslado de norte la primera idea es la de la influencia árabe. La cultura árabe influyó mucho al mundo europeo y dió al español, y no sólo a él, algunos nombres de estrellas como Aldebarán, Altair, Vega, ésta del ár. an-nasr al waquic "estrella fugaz" (v. Giovan Battista Pellegrini, Gli arabismi nelle lingue neolatine, I, Brescia 1972, p. 78) o términos científicos en el campo semántico de astronomía como acimut, cenit, nadir, auge. Por cierto, los astros tienen en la vida árabe una singular importancia. Parece, todavía, que el término para el norte, punto cardinal, no sea usado metonímicamente para "estrella polar", ni metafóricamente para "personaje de seguir".

Por lo tanto, parece no quedar otra explicación que la del habla de los navegantes. Cervantes tuvo que estar en contacto no sólo fugazmente con la vida del mar. Los pocos pasos citados, literarios, de las tres lenguas románicas mediterráneas señalan, sí, el término norte en su uso metafórico, siempre en el sentido relativamente abstracto de "ideal", "norma", "modelo de seguir", es decir, su empleo es muy intelectual. En la metáfora cervantina, fruto de la fantasía creadora del artista, al contrario, es el personaje carismático que aparece y es concreto, vivo.

\section{Povzetek}

\section{METAFORA PRI CERVANTESU: SEVER}

Sever je $\mathrm{v}$ Don Kihotu rabljen v svojem prvotnem pomenu, je pa tudi metonimija za "zvezdo severnico" in odtod še metafora, ali močno razumsko in literarno "vodilo, zgled" ali močno kreativno in emfatično: karizmatična oseba.

V svojem bleščečem prevodu (Veleumni plemič don Kihot iz Manče, DZS, Ljubljana 1973) se je prevajalec Niko Košir izognil metonimičnemu izrazu sever, ki bi zvenel v slovenščini nenavadno, celo nerazumljivo, s svojim znanim mojstrstvom pa je znal ohraniti ves čar Cervantesove metafore: Takisto je bil Amadis zvezda severnica, zvezda danica, sonce srčnih in zaljubljenih vitezov (I/25); Svetilnik, luč, stezá, tečaj, vodnik... don Kihot, ti zvezda Španije in slava Manče. (II/35); Dobrodošlo v našem mestu ogledalo, svetilnik, zvezda in kažipot vsega blodečega viteštva (II/61). 